\title{
CHARACTERIZATION OF ODOROUS EMISSIONS FROM A CIVIL WASTEWATER TREATMENT PLANT IN ITALY
}

\author{
MARCO RAVINA ${ }^{1}$, DEBORAH PANEPINTO ${ }^{1}$, JHEYSON MEJIA ESTRADA ${ }^{2}$, LUCA DE GIORGIO ${ }^{3}$, \\ PIETRO SALIZZONI ${ }^{2}$, MARIA CHIARA ZANETTI ${ }^{1} \&$ LORENZA MEUCCI $^{3}$ \\ ${ }^{1}$ Department of Environment, Land and Infrastructure Engineering, Politecnico Di Torino, Italy \\ ${ }^{2}$ Laboratoire de Mécanique des Fluides et d'Acoustique, University of Lyon, France \\ ${ }^{3}$ SMAT Research Centre, Italy
}

\begin{abstract}
The characterization and reduction of odour emissions represents an open debate among the scientific community. Odour nuisances are connected to a large number of substances, mostly detectable at low concentrations. Direct estimation of odour impacts through olfactometry is not always applicable, as this approach requires air sampling and a pool of trained panellists. Measuring the concentration of odorous substances provides support to the characterization of emission sources and the design of odour monitoring systems. Civil wastewater treatment plants (WWTPs) are known sources of odours. The objective of this project is the design and development of an integrated odour emission monitoring system at the Castiglione Torinese WWTP in Italy. In this paper, the preliminary characterization of the emission sources and the odour emitting components are presented. The characterization of the emission sources and tracers was obtained by mean of a number of site inspections and measurement campaigns held between 2017 and 2019. In the last campaign, held in January 2019, chemical odour tracers $\left(\mathrm{H}_{2} \mathrm{~S}, \mathrm{NH}_{3}, \mathrm{VOC}\right)$ and dynamic olfactometry measurements were performed simultaneously. The screening of VOC species through gas chromatograph/mass spectrometer analysis of air samples was also performed. Odour emitting components were ranked in terms of odour activity value (OAV). Results show that VOC is the only group of compounds that is always detectable on the site. $\mathrm{NH}_{3}$ and $\mathrm{H}_{2} \mathrm{~S}$ may, in some cases, be present at considerable concentrations. Results of OAV calculations show that a number of VOCs are detected on the site with a high spatial and temporal frequency. Additional considerations are reported on the site-specific correlation between chemical species and odour measurements. This detailed characterization of the emission sources and tracers results in the design of the final integrated monitoring system, which will be based on continuous measurement of $\mathrm{H}_{2} \mathrm{~S}, \mathrm{NH}_{3}$ and $\mathrm{VOC}$ and advanced dispersion modelling.

Keywords: odour monitoring, wastewater treatment, odour dispersion modelling, odour activity value, odour tracers, olfactometry.
\end{abstract}

\section{INTRODUCTION}

Odours procure nuisance among the population and have been reported to increase health effects even with no toxic concentration [1]. Odour nuisances are connected to a large number of chemical substances, mostly detectable at low concentration thresholds. Civil wastewater treatment plants (WWTPs) are known sources of odours. The analysis of odour impacts in civil WWTPs is a challenging task, due to the design of this kind of plants.

Many factors influence whether an emission will produce disturbing impacts: odorants are characterized by specific sensorial properties, and co-existing odorants may be subject to interactive effects. The need to regulate odour impacts requires specific methods for odour measurement and assessment. Odour control strategies depend on the knowledge of the interactions between its chemical components and their dilution in the atmosphere after being emitted [2]. At today, the application of olfactometry methods present some limitations due to (i) the high costs of air sampling and subsequent laboratory analysis; and (ii) the impossibility of continuous measurements [3]. The application of electronic noses, although promising, is still limited, due to technological problems, as sensor drift over time and 
undesired sensor sensitivity to variable atmospheric conditions [4]. In addition, electronic noses are still not representative of the odour impacts in case a complex mixture of odorants is assessed. Using analytical techniques, i.e. concentrations measurements of odorous substances, is not directly correlated to the determination of odour properties. Nevertheless, the chemical identification of odorous compounds is necessary for odour monitoring and abatement. With the purpose of relating a chemical composition of an odorous mixture to its odour concentration, different methods were proposed. These methods include the odour activity value (OAV [5]), the sum of the individual odour intensities (SOI [6]) and the equivalent odour concentration (EOC [7]). Odour activity value (OAV) represents an established methodology for obtaining significant information about odours based on the results of chemical analyses in the field [8]. OAV, being a sort of total concentration weighted by the odour thresholds of the single compounds contained in an odorous mixture, does account for the different relative contribution of each compound to the mixture total odour concentration, and therefore is able to better describe the odour properties of an odorous mixture than just the total VOC. The main critical aspects of this method are those related to concentration measurement of odorant species, i.e. the detection limit of the instruments and the complete characterization of all possible odorants.

In order to obtain a continuous and complete monitoring of odour impacts, the methods based on analytical measurements must be connected to dispersion modelling. Odour dispersion modelling allows the evaluation of spatial and temporal distribution of odour impacts. For this reason, modelling is essential to characterize the possible sources of odour nuisances and take relevant remedies. Modelling odours emitted by WWTPs follows the general approach of other types of sources. In general, non-stationary Lagrangian puff and particle models have to be preferred to Gaussian models, due to the inability of these latter to handle calm and stagnation conditions, lack of three-dimensional meteorology and steadystate assumption [4]. The main issue with odour modelling is that to fully predict odour annoyance, the fluctuations of concentrations at a small time scale (second or minute) at the receptor are critical.

Owing to these considerations, the characterization of odorous emissions from WWTPs requires an integrated approach, in which analytical, olfactory and modelling methodologies are applied and linked. The objective of this research project is to propose the design and development of such an integrated odour emission monitoring system. The SMAT's wastewater treatment plant (WWTP), the largest chemical, physical and biological treatment plant in Italy, was used as a case study.

The monitoring system is composed by a network of fixed continuous measurement stations on the site, and the development of a modelling chain simulating the local dispersion of odour emissions in the area. The system must be designed in ways to analyse the possible contribution of SMAT's WWTP to odour nuisances in case of complaints of the citizens. This paper starts from presenting the results of the emission characterization phase. Based on this characterization, the methodology and features of the continuous monitoring system design were defined and discussed.

\section{MATERIALS AND METHODS}

The research project has been developed through the following phases:

- characterization of the emission sources and the chemical species used as indicators of odour emissions;

- selection and design of the continuous monitoring system; and 
- connection of the continuous monitoring system to the modelling chain for the analysis and evaluation of odour nuisance episodes.

\subsection{Site description}

SMAT's centralized civil WWTP is the largest chemical, physical and biological treatment plant in Italy. The plant treats municipal and industrial wastewater with a capacity of more than 2,000,000 of equivalent inhabitants. It consists of four lines devoted to the wastewater treatment and one line for sludge treatment. The water line, with an average flow rate of about $25,000 \mathrm{~m}^{3} / \mathrm{h}$, is made up of the following processes: grid screens, grit and grease removal, primary sedimentation, pre-denitrification, biological treatment, secondary sedimentation, phosphorous removal and final filtration (Fig. 1).

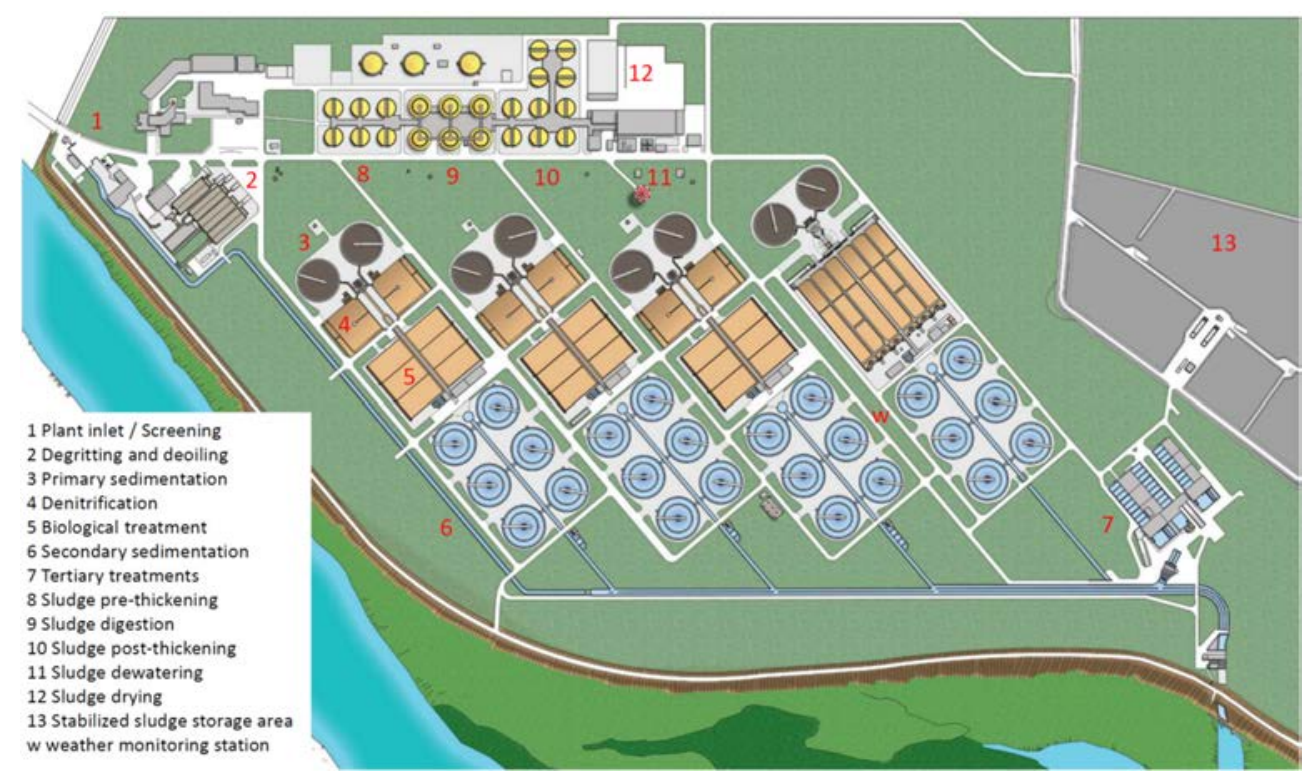

Figure 1: Plant of SMAT's WWTP [9].

In September 2017, a weather monitoring station was installed onsite. The location was selected in way to avoid any potential disturbance of air circulation generated by structural elements.

The datalogging system provides average values of the weather variables over 10 minutes.

The average wind distribution recorded in the period September 2017-March 2019 show different wind distribution between night time and day time. Night time is characterized by low wind (around $0.5-1 \mathrm{~m} / \mathrm{s}$ ) with main direction SE. Day time is characterized by slightly higher wind (up to $5 \mathrm{~m} / \mathrm{s}$ ) with main direction NE. No significant seasonal variation is evidenced, although higher variability of wind distribution appears during spring and winter.

\subsection{Emission sources characterization}

A preliminary characterization phase was conducted to evaluate the odour emission sources. This phase had the objective of defining the areas of the WWTP with a major influence on 
odour impacts. To this end, five monitoring campaigns were held onsite between October 2017 and January 2019. Each campaign aimed at characterizing different aspects. A brief description of the objectives, methods and chemical species considered for each campaign is reported in Table 1.

Table 1: Measurement campaigns description.

\begin{tabular}{|c|c|c|c|c|}
\hline ID & Date & Objective & Description & Measures \\
\hline 1 & Oct-17 & $\begin{array}{l}\text { Preliminary screening } \\
\text { of emission sources }\end{array}$ & $\begin{array}{l}\text { All components of the } \\
\text { process monitored in } \\
\text { three separate days }\end{array}$ & $\mathrm{VOC}, \mathrm{NH}_{3}$ \\
\hline 2 & Nov-17 & $\begin{array}{l}\text { Spatial and temporal } \\
\text { analysis of main } \\
\text { emission sources } \\
\text { selected after } \\
\text { Campaign } 1\end{array}$ & $\begin{array}{l}\text { Concentrations were } \\
\text { measured in different } \\
\text { days at different times; } \\
\text { close to the emission } \\
\text { source and at a distance } \\
\text { of } 10 \mathrm{~m}\end{array}$ & VOC, $\mathrm{NH}_{3}$ \\
\hline 3 & Mar-18 & $\begin{array}{l}\text { Characterization of } \\
\text { volatile compounds } \\
\text { emitted by the plant }\end{array}$ & $\begin{array}{l}\text { Contemporary } \\
\text { concentrations } \\
\text { measurement and } \\
\text { samples collection for } \\
\text { GC-MS analysis }\end{array}$ & $\mathrm{VOC}, \mathrm{H}_{2} \mathrm{~S}$ \\
\hline 4 & May-18 & $\begin{array}{l}\text { Analysis of } \\
\text { endogenous/exogenous } \\
\text { contribution of } \\
\text { emission sources to } \\
\text { concentrations }\end{array}$ & $\begin{array}{l}\text { Concentrations were } \\
\text { measured close to the } \\
\text { emission sources and at } \\
\text { the site boundaries }\end{array}$ & VOC \\
\hline 5 & Jan-19 & $\begin{array}{l}\text { Analysis of the } \\
\text { relationship between } \\
\text { concentrations and } \\
\text { odours }\end{array}$ & $\begin{array}{l}\text { Contemporary } \\
\text { concentrations } \\
\text { measurement and } \\
\text { samples collection for } \\
\text { olfactometry and GC- } \\
\text { MS analysis }\end{array}$ & $\begin{array}{c}\text { VOC, } \mathrm{NH}_{3}, \mathrm{H}_{2} \mathrm{~S}, \\
\text { olfactometry }\end{array}$ \\
\hline
\end{tabular}

The analysis focused on three group of chemical species, i.e. $\mathrm{H}_{2} \mathrm{~S}, \mathrm{NH}_{3}$ and VOC. VOC concentration was measured with the use a portable photo ionization detector (PID, model Tiger, ION Science, $0.1 \mathrm{ppb}$ of resolution). $\mathrm{NH}_{3}$ concentration was measured with the use a portable electrochemical device (model Gas Alert Extreme, BW Technologies, 0.1 ppm of resolution). $\mathrm{H}_{2} \mathrm{~S}$ concentration measurements were contracted to an external laboratory, and executed according to NIOSH 6013-1994 method.

In the last monitoring campaign, measurements of $\mathrm{VOC}, \mathrm{H}_{2} \mathrm{~S}$ and $\mathrm{NH}_{3}$ concentrations were done in parallel with air sampling and subsequent olfactometry analysis by an external laboratory. A total of 20 samples were collected, 17 samples of ambient air and three from diffused sources. Ambient air samples were collected in nalophan bags. Samples from diffused sources (degritting tank, primary sedimentation tank and stabilized sludge storage area) were collected by wind tunnel sampling. Odour concentrations were determined in a ODOURNET TO8 olfactometer according to standard EN 13725:2004. 


\subsection{VOC screening and data processing}

A VOC screening was performed during Campaigns 3 and 5. This phase had the objective of characterizing the chemical species emitted by the WWTP and detecting possible odours tracers. The data were subsequently used for evaluating a possible correlation between VOC and odour concentrations. VOC screening in Campaign 3 was done according to EN ISO 16017-1:2002 method. Six air samples were collected in the following areas of the plant: plant inlet, grit removal, primary settler, sludge drying, stabilized sludge external storage, sludge thickening. Air samples were collected on adsorption tubes, then analysed in a laboratory with a gas chromatograph/mass spectrometer (GC-MS). VOC screening in Campaign 5 was done according to EPA-TO-15 1999 method. In this latter campaign, three air samples were collected, two from ambient air (plant inlet and sludge drying) and one by means of wind tunnel sampling (external sludge storage).

Data collected from the monitoring campaigns (concentrations and VOC screening) were used to calculate the odour activity value (OAV) of single species. OAV is defined as the ratio of the concentration of a specific odorant to its odour threshold (OT) value. The sum of single OAVs (SOAV) was then calculated. Odour thresholds of single substances were taken by Nagata [10] and integrated with additional sources [11], [12].

For Campaign 5, a specific OU/SOAV ratio for each measurement point was calculated. The following methodology was used:

- A VOC profile was assigned to each point depending on its location on the area. The VOC profile was selected from the VOC screening performed in Campaign 3 (six samples).

- Total VOC concentration measured with the portable instrument was divided following the VOC profile assigned, obtaining concentrations of single species.

- OAV and SOAV were calculated in each point.

- Measured odour concentration was divided by the SOAV, obtaining a specific OU/SOAV ratio for each sampling point.

\section{RESULTS}

Results of measurement campaigns and data elaboration, as well as the main features of the integrated odour monitoring system, are presented in this section.

\subsection{Results of monitoring campaigns}

The results of the monitoring campaigns are resumed in Fig. 2.

During Campaign 1, on average, VOC concentrations were higher next to preliminary treatment section, primary settling and sludge de-watering section. There is agreement in the scientific literature that these treatment stages represent the most important contributions to odour emissions in civil WWTPs [13], [14]. Concentrations were lower downstream of the primary treatment (nitrification tanks and secondary settlers). $\mathrm{NH}_{3}$ concentration was below the detection limit of the instrument $(0.1 \mathrm{ppm})$, with the only exception of two areas: $2 \mathrm{ppm}$ in correspondence of the plant inlet (degritting stage), and $2 \mathrm{ppm}$ in correspondence of Module 2 secondary settling stage.

During Campaign 2, measurements were restricted to the areas with higher concentration in Campaign 1. In these areas, VOC concentrations were measured close to the emission source or in the immediate proximity (around $5 \mathrm{~m}$ ). Results of Campaign 2 showed that concentration values quickly decay by moving away from the emission sources, indicating a 


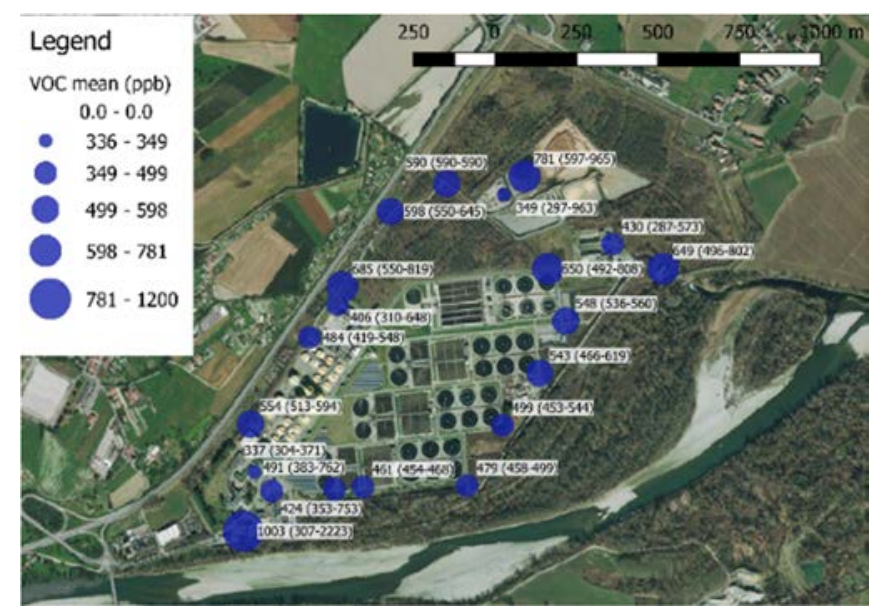

Figure 2: Mean, maximum and minimum VOC concentrations measured in monitoring campaigns.

rapid dispersion of the contaminants. Concentrations measurements of $\mathrm{NH}_{3}$ confirmed the results of Campaign 1. Results of Campaign 3 confirmed the results of previous campaigns, evidencing a higher VOC concentration in correspondence of the plant inlet and the sludge drying area. Considering $\mathrm{H}_{2} \mathrm{~S}$ measurements of Campaign 3, the concentration was below the detection limit of the method $\left(0.0556 \mu \mathrm{g} / \mathrm{m}^{3}\right)$ in four of the six sampling points. $\mathrm{H}_{2} \mathrm{~S}$ concentration of $1.2 \mu \mathrm{g} / \mathrm{m}^{3}$ was measured next to the grit removal stage and a value of $16 \mu \mathrm{g} / \mathrm{m}^{3}$ next to the primary settling stage. These values show that $\mathrm{H}_{2} \mathrm{~S}$ may, in some circumstances, be present at values above its odour threshold, that is around $0.6 \mu \mathrm{g} / \mathrm{m}^{3}$. VOC measurements of Campaigns 4 and 5 were extended to the whole plant area (Fig. 2). These latter campaigns evidence a significant variability of VOC concentration around the plant, with high background values in the order of $350-680 \mathrm{ppb}$. It is expected that the presence of VOC in the area was also due to the possible contribution of external sources. These external sources may be represented by the adjacent motorway, by the industrial site located $3 \mathrm{~km}$ north of the plant and by the surrounding agricultural activities. Results of parallel measurements of VOC, H2S, NH3 and OU of Campaign 5 are reported in Table 3. Odour concentration was higher in correspondence of the degritting tank, primary settler and (mostly) in the stabilized sludge external storage area. A significant difference in concentration is found between wind tunnel and ambient air samples.

\subsection{VOC screening and SOAV calculation}

In VOC screening, 132 species were detected in Campaign 3 and 40 species in Campaign 5. Provided that a higher number of species and chemical groups was analysed, results of Campaign 3 were considered more precise and used in the subsequent stage of analysis.

VOC screening of Campaign 3 showed that the main family of compounds are aromatics, aldehydes and halogenated aliphatics. Few species were detected in all sampling points. These are: tetrachlorethylene (average concentration on all sampling points of $2.73 \mu \mathrm{g} / \mathrm{m}^{3}$ ), toluene $\left(6.33 \mu \mathrm{g} / \mathrm{m}^{3}\right), \mathrm{m}+\mathrm{p}$-xylene $\left(2.88 \mu \mathrm{g} / \mathrm{m}^{3}\right)$, limonene $\left(4.36 \mu \mathrm{g} / \mathrm{m}^{3}\right)$ and dimethyl disulfide (DMDS, $0.46 \mu \mathrm{g} / \mathrm{m}^{3}$ ). The same compounds are reported in similar studies on odour emissions from civil WWTPs found in bibliography [15], [16]. 
The list of VOC species with highest OAV and the SOAV for Campaigns 3 and 5 is reported in Table 2. For Campaign 3, a SOAV between 6.10 and 30.39 is found. Major contribution to SOAV can be assigned to four chemical groups or species in order of importance: aldehydes, sulphur compounds $\left(\mathrm{H}_{2} \mathrm{~S}\right.$ and DMDS), ethylbutyrate and propionic acid. $\mathrm{H}_{2} \mathrm{~S}$ contributes to the $87 \%$ of the SOAV in correspondence of the primary settler, and to the $26 \%$ in correspondence of the grit removal stage. These results show that, if present, $\mathrm{H}_{2} \mathrm{~S}$ contributes significantly to odour emission at the SMAT's WWTP. The results of Campaign 5 show that aldehydes, octanal and decanal in particular, give the major contribution to SOAV. DMDS is also present in correspondence of the external sludge storage area. SOAV at the plant inlet and sludge de-watering area of Campaign 5 is higher than that of Campaign 3, due to the relevant contribution of octanal to total odour activity $(55-68 \%)$.

Table 2: SOAV and chemical species with higher OAV in Campaign 3 and Campaign 5.

\begin{tabular}{|c|c|c|c|c|}
\hline \multirow{2}{*}{$\begin{array}{l}\text { Plant section } \\
\text { (composition } \\
\text { profile) }\end{array}$} & \multicolumn{2}{|r|}{ Campaign 3} & \multicolumn{2}{|r|}{ Campaign 5} \\
\hline & SOAV & Species with higher OAV & SOAV & Species with higher OAV \\
\hline $\begin{array}{l}\text { Plant inlet } \\
\text { (P1) }\end{array}$ & 6.10 & $\begin{array}{l}\text { Acetaldehyde } 1.090 ; \\
\text { Ethylbutyrate } 0.990 ; \\
\text { Butirraldehyde } 0.721 ; \\
\text { Propionic acid } 0.592 ; \\
\text { Octane } 0.434\end{array}$ & 38.77 & $\begin{array}{l}\text { Octanal } 21.359 \\
\text { Decanal } 8.766 \\
\text { Acetic acid } 3.620 \\
\text { Nonanal } 1.610 \\
\text { Hexanal } 1.465\end{array}$ \\
\hline $\begin{array}{l}\text { Grit removal } \\
(\mathrm{P} 2)\end{array}$ & 7.71 & $\begin{array}{l}\text { Hydrogen sulphide } 2.000 \\
\text { Acetaldehyde } 1.371 \\
\text { Butirraldehyde } 0.914 \\
\text { Propionic acid } 0.751 \\
\text { Propionaldehyde } 0.440 \\
\end{array}$ & - & - \\
\hline $\begin{array}{l}\text { Primary } \\
\text { settler (P3) }\end{array}$ & 30.39 & \begin{tabular}{|l} 
Hydrogen sulphide \\
26.664 \\
Acetaldehyde 1.090 \\
Butirraldehyde 0.673 \\
Propionic acid 0.462 \\
Propionaldehyde 0.336
\end{tabular} & - & - \\
\hline $\begin{array}{l}\text { Sludge } \\
\text { thickening } \\
\text { (P4) }\end{array}$ & 19.08 & $\begin{array}{l}\text { Ethylbutyrate } 9.036 \\
\text { Propionic acid } 1.954 \\
\text { 4-isopropyltoluene } 1.354 \\
\text { 3-isopropyltoluene } 1.279 \\
\text { Phenol } 0.964\end{array}$ & - & - \\
\hline $\begin{array}{l}\text { Sludge } \\
\text { drying (P5) }\end{array}$ & 7.22 & $\begin{array}{l}\text { dimethyl disulfide } 2.228 \\
\text { Acetaldehyde } 1.336 \\
\text { Butirraldehyde } 1.154 \\
\text { Ammonia } 0.684 \\
\text { dimethyl trisulfide } 0.462\end{array}$ & 44.32 & $\begin{array}{l}\text { Octanal } 30.437 \\
\text { Decanal } 4.127 \\
\text { Heptanal } 3.153 \\
\text { Hexanal } 2.352 \\
\text { Nonanal } 2.515 \\
\end{array}$ \\
\hline $\begin{array}{l}\text { Stabilized } \\
\text { sludge } \\
\text { external } \\
\text { storage (P6) }\end{array}$ & 9.47 & $\begin{array}{l}\text { Propionic acid } 4.593 \\
\text { Acetaldehyde } 1.195 \\
\text { Butirraldehyde } 0.914 \\
\text { Ammonia } 0.620 \\
\text { 4-isopropyltoluene } 0.461\end{array}$ & 16.13 & $\begin{array}{l}\text { Disulfide,dimethyl } 7.143 \\
\text { Hexanal } 5.321 \\
\text { Toluene } 1.476 \\
\text { 1-Butanol } 0.800 \\
\text { Benzene,1,2,4-trimethyl-0.635 }\end{array}$ \\
\hline
\end{tabular}




\section{$3.3 \mathrm{OU} / \mathrm{SOAV}$ ratio}

Starting by the parallel olfactometry and chemical measurements of Campaign 5, a OU/SOAV ratio was calculated for each of the 20 sampling points. To calculate SOAV, a specific composition profile between those of Campaign 3 was assigned to each point (Table 3 ). Total VOC concentration was divided into concentration of single species depending on the composition profile assigned. Composition profiles were selected from Campaign 3 because of the higher precision of the VOC screening performed in this campaign. OAV of single species was calculated and then summed up to obtain SOAV. For each sampling point, OU concentration was then divided by the SOAV and a OU/SOAV ratio was obtained. The results are reported in Table 3. Different values of OU/SOAV ratio were found if the odour concentration was determined through wind tunnel or ambient air sampling. In the first case, a OU/SOAV between 1.04 and 10.31 was found. In the second case, the OU/SOAV ratio ranged between 0.11 and 0.46 .

Table 3: Calculation of OU/SOAV ratio for the sampling points of Campaign 5.

\begin{tabular}{|c|l|c|c|c|c|c|}
\hline ID & Plant area & $\begin{array}{c}\text { VOC } \\
\text { concentration } \\
(\mathrm{ppb})\end{array}$ & $\begin{array}{c}\text { SOAV } \\
\text { profile }\end{array}$ & $\begin{array}{c}\text { SOAV } \\
\text { calculated }\end{array}$ & $\begin{array}{c}\text { OU } \\
\text { concentration } \\
\left(\mathrm{OU} / \mathrm{m}^{3}\right)\end{array}$ & OU/SOAV \\
\hline 1 & Plant inlet & 1512 & P1 & 357.1 & 47 & 0.13 \\
\hline 2 & Grit removal* $^{*}$ & 753 & P2 & 172.8 & 180 & 1.04 \\
\hline 3 & Primary settler* & 756 & P3 & 114.9 & 540 & 4.70 \\
\hline 4 & Sludge drying & 648 & P5 & 127.9 & 33 & 0.26 \\
\hline 5 & $\begin{array}{l}\text { Stabilized sludge } \\
\text { external storage }- \\
\text { position 1* }\end{array}$ & 963 & P6 & 348.5 & 1100 & 3.16 \\
\hline 6 & $\begin{array}{l}\text { Stabilized sludge } \\
\text { external storage }- \\
\text { position 2* }\end{array}$ & 964 & P6 & 349.2 & 3600 & 10.31 \\
\hline
\end{tabular}

*Wind tunnel sampling.

\subsection{Integrated odour monitoring system}

The results of preliminary monitoring campaigns of $\mathrm{VOC}, \mathrm{NH}_{3}$ and $\mathrm{H}_{2} \mathrm{~S}$ may be resumed with the following considerations:

- VOC is the only group of compounds that was always detectable on the site. Nevertheless, it could not be excluded that $\mathrm{NH}_{3}$ and $\mathrm{H}_{2} \mathrm{~S}$ may be present at considerable concentration and contribute significantly to odour impacts.

- A number of areas in the site may be detected and evidenced as primary emission sources of VOC to be potentially linked to odour emission. These areas are the preliminary treatments, primary settling, sludge drying and sludge thickening. The stabilized sludge external storage area should also be considered as a primary emission source, as characterized by the highest odour concentration. Other areas may be defined as secondary emission sources. These are aeration tanks, secondary settling tanks and sludge thickening area. 
- If measurements are taken moving away from the emission source, concentrations show a significant variability in space and magnitude. Information collected is not sufficient to directly evaluate the possible contribution of external sources to total concentration.

The VOC screening of Campaigns 3 and 5 provided information on the chemical composition of the compounds emitted by the WWTP or present in the area. A number of species or groups may be found in the whole area and associated with the emission sources. Future monitoring campaigns on the emission sources surrounding the area of study could provide additional information in order to define possible chemical tracers for odour nuisances. Results of VOC screening were also elaborated to study the link between chemical and odour concentrations. The resulting values of OU/SOAV ratios were used to link chemical measurements to the modelling of odour emissions.

The resulting general scheme of the integrated odour monitoring system is reported in Fig. 3. Starting from VOC, $\mathrm{H}_{2} \mathrm{~S}$ and $\mathrm{NH}_{3}$ concentration measurements, odour concentration is estimated with the method described in Section 3.3. Odour concentrations are used to calculate odour emission rates for primary and secondary sources. Odour emission rates are thus introduced into a dispersion model to evaluate the magnitude and spatial distribution of odours. The system is designed to operate in near-real time, i.e. receiving weather data and concentrations from the monitoring stations, processing them and running the dispersion model without a significant delay (in the order of minutes to hours). This is achieved by mean of a set of algorithms that (i) manages and synchronizes data acquisition from weather and concentration sensors; (ii) converts chemical concentrations into odour concentration; (iii) calculates odour emission flow; and (iv) prepares the input and runs the dispersion models.

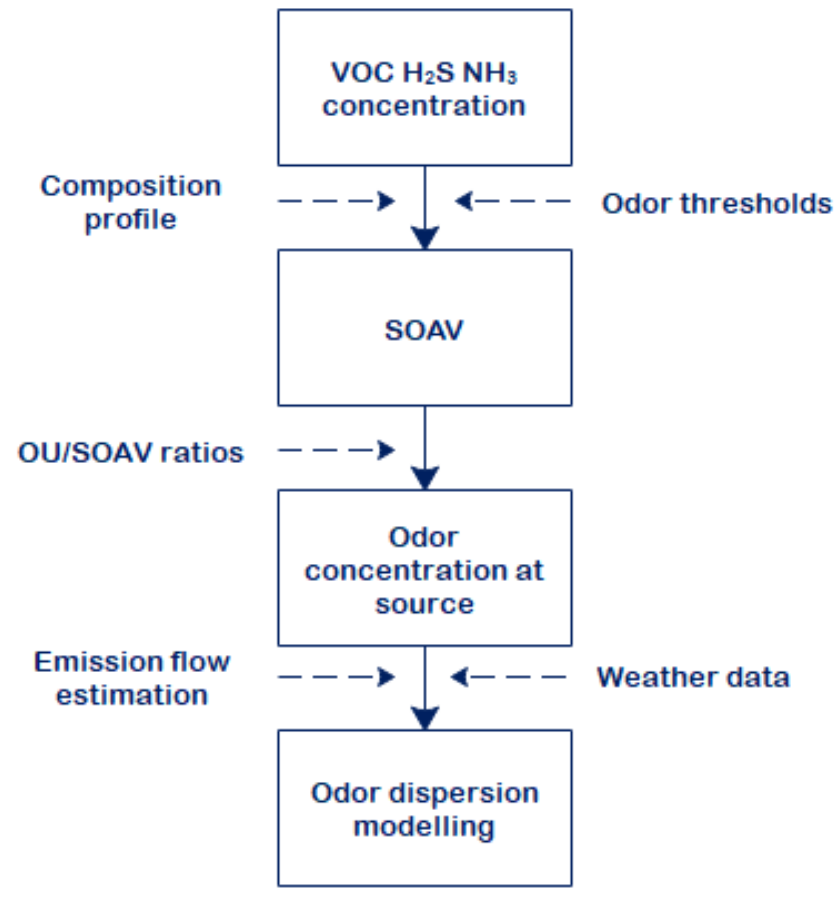

Figure 3: Operating scheme of the continuous odour monitoring system. 
The system for the continuous measurement of chemical species is composed by a monitoring station for every emission source. Each unit is equipped with sensors for VOC, $\mathrm{NH}_{3}$ and $\mathrm{H}_{2} \mathrm{~S}$ measurement. The sensors have low detection limits, in the order of $10 \mathrm{ppb}$ for VOC, $0.5 \mathrm{ppm}$ for $\mathrm{NH}_{3}$ and $10 \mathrm{ppb}$ for $\mathrm{H}_{2} \mathrm{~S}$ respectively. Similarly, the measuring range of the sensors must be wide enough to cover possible concentration peaks (in the order of 0-15 ppm for VOC, $0-25 \mathrm{ppm}$ for $\mathrm{NH}_{3}$ and $0-1000 \mathrm{ppb}$ for $\mathrm{H}_{2} \mathrm{~S}$ respectively). The sampling frequency is 10 minutes, adequate to the analysis of peak emission episodes.

Specific gas sensors commercially available comprise a broad variety of chemical, electrochemical, catalytic, and optical detectors with a high sensitivity and selectivity for some target odorants. They present low response times and low cost. Their main drawback is that they are susceptible of interferences from humidity [17]. To address this problem, some of these sensors have been equipped with a specific filter (e.g. the CairClip sensors, EnveaTM [18]).

The modelling system is going to be based on the Safety Atmospheric Lagrangian Model (SLAM) developed at Laboratory of Fluid Mechanics and Acoustics of Lyon University, France [19]. SLAM is composed by two main modules: the first is devoted to meteorological data processing and extraction of the wind field, the second to pollutant dispersion. The meteorological pre-processor is based on Monin-Obukhov similarity theory. The dispersion module simulates the trajectories of a large number of particles from an increased average velocity field at every point and at each iteration of a random component representing the turbulent fluctuation.

\section{CONCLUSION}

This paper had the objective of defining the design of an integrated system for the continuous monitoring of odour emissions at SMAT's WWTP. The preliminary scientific and experimental characterization phase provided the relevant information to overcome this objective. The integrated monitoring system will be managed by a novel set of algorithms that (i) collect and synchronize data acquisition from weather and concentration sensors; (ii) convert chemical concentrations into odour concentration; (iii) calculate odour emission flow; and (iv) prepare the input and runs the dispersion models. Given its high level of automation, the system will allow a fast reproduction of odour dispersion in case of odour nuisance episodes, providing information on the contribution of SMAT's WWTP to odour impacts in the surroundings.

In the study of odour quantification and minimization, several aspects remain unresolved, due to the complexity of the topic. These aspects include the measurement methods (chemical analyses, olfactometry, electronic noses), the characterization of odorants (in particular, odour thresholds), the characterization of additive or synergistic effects and the dispersion modelling phase (definition of odour emission rates and peak concentrations). The sensitivity of population to odour problems is constantly increasing, since odours have been demonstrated to affect citizens' health and not only cause nuisance. Seen this, a trade-off between scientific knowledge and the necessity of providing technological solutions is needed. The system presented herein attempts to provide such a solution. It is expected that its design and features shall be improved after entering into operation. In this sense, additional field measurements will provide further details. Also, the implementation of alternative methods for i) the conversion of chemical concentrations into odour units and ii) the estimation of concentration fluctuation shall be tested on the system. As a final result of this research project, SMAT's WWTP will be equipped with a complete and integrated monitoring system of odour emissions. The same methodology may, in principle, be extended to other WWTPS, as well as other typologies of odour emitting sources. 


\section{ACKNOWLEDGEMENT}

The authors acknowledge SMAT company for the support and the data provided.

\section{REFERENCES}

[1] Hayes, J.E., Stevenson, R.J. \& Stuetz, R.M., The impact of malodour on communities: A review of assessment techniques. Sci. Total Environ., 500-501, pp. 395-407, 2014. DOI: $10.1016 /$ j.scitotenv.2014.09.003.

[2] Carrera-Chapela, F., Donoso-Bravo, A., Souto, J.A. \& Ruiz-Filippi, G., Modeling the odour generation in WWTP: An integrated approach. Rev. Water Air Soil Pollut., 225, p. 1932, 2014. DOI: 10.1007/s11270-014-1932-y.

[3] Gostelow, P., Parsons, S.A. \& Stuetz, R.M., Odour measurements for sewage treatment works. Water Res., 35, pp. 579-597, 2001.

[4] Capelli, L., Sironi, S., Del Rosso, R. \& Guillot, J.M., Measuring odours in the environment vs. dispersion modelling: A review. Atmos. Environ., 79, pp. 731-743, 2013. DOI: 10.1016/j.atmosenv.2013.07.029.

[5] Rincon, C.A. et al., Odour concentration (OC) prediction based on odour activity values (OAVs) during composting of solid wastes and digestates. Atmos. Environ., 201, pp. 1-12, 2019. DOI: 10.1016/j.atmosenv.2018.12.030.

[6] Kim, K.H. \& Park, S.Y., A comparative analysis of malodor samples between direct (olfactometry) and indirect (instrumental) methods. Atmos. Environ., 42, pp. 50615070, 2008. DOI: 10.1016/j.atmosenv.2008.02.017.

[7] Wu, C., Liu, J., Zhao, P., Piringer, M. \& Schauberger, G., Conversion of the chemical concentration of odorous mixtures into odour concentration and odour intensity: A comparison of methods. Atmos. Environ., 127, pp. 283-292, 2016.

DOI: 10.1016/j.atmosenv.2015.12.051.

[8] Lebrero, R., Bouchy, L., Stuetz, R. \& Muñoz, R., Odour assessment and management in wastewater treatment plants: A review. Crit. Rev. Env. Sci. Tec., 41(10), pp. 915950, 2011. DOI: 10.1080/10643380903300000.

[9] SMAT (Società Metropolitana Acque Torino). www.smatorino.it/. Accessed on: 6 May 2019.

[10] Nagata, Y., Measurement of odor threshold by triangle odor bag method. Odor Measurement Review, Japan Ministry of the Environment, pp. 118-127, 2003.

[11] van Gemert, L.J., Odour Thresholds. Compilations of Odour Threshold Values in Air, Water and Other Media. Oliemans Punter \& Partners BV: The Netherlands, 2011.

[12] Dunlop, M.W., Blackall, P.J. \& Stuetz, R.M., Odour emissions from poultry litter: A review litter properties, odour formation and odorant emissions from porous materials. J. Environ. Manage., 177, pp. 306-319, 2016. DOI: 10.1016/j.jenvman.2016.04.009.

[13] Talaiekhozani, A., Bagheri, M., Goli, A. \& Khoozani, M., An overview of principles of odour production, emission, and control methods in wastewater collection and treatment systems. J. Environ. Manage., 170, pp. 186-206, 2016.

DOI: 10.1016/j.jenvman.2016.01.021.

[14] Lin, J., Li, L., Liu, J. \& Li, M., Odours and volatile organic compounds emission from main processing units of wastewater treatment plant. Chinese J. Environ. Eng., 10, pp. 2329-2334, 2016.

[15] Sivret, E.C., Wang, B., Parcsi, G. \& Stuetz, R.M., Prioritisation of odorants emitted from sewers using odour activity values. Water Res., 88, pp. 308-321, 2016. DOI: 10.1016/j.watres.2015.10.020.

[16] Fisher, R.M., Le-Minh, N., Sivret, E.C., Alvarez-Gaitan, J.P., Moore, S.J. \& Stuetz, R.M., Distribution and sensorial relevance of volatile organic compounds emitted 
throughout wastewater biosolids processing. Sci. Total Environ., 599-600, pp. 663670, 2017. DOI: 10.1016/j.scitotenv.2017.04.129.

[17] Brattoli, M., de Gennaro, G., de Pinto, V., Demarinis Loiotile, A., Lovascio, S., Penza, M., Odour detection methods: Olfactometry and chemical sensors. Sensors, 11, pp. 5290-5322, 2011. DOI: 10.3390/s110505290.

[18] EnveaTM, CairClip sensors. http://cairpol.com/en/home/. Accessed on: 6 May 2019.

[19] Vendel, F., Soulhac, L., Mejean, P., Donnat, L. \& Duclaux, O., Validation of the Safety Lagrangian Atmospheric Model (SLAM) against a wind tunnel experiment over an industrial complex area. 14th International Conference on Harmo, within Atmos. Disp. Modell. for Regul. Purposes, Kos, Greece, 2011. 